\title{
En tre år gammel jente med magesmerter og feber
}

\author{
Ved feber hos barn kan det ofte være utfordrende å finne årsaken, \\ spesielt dersom symptomene kommer og går. Etnisiteten kan være \\ nøkkelen til riktig diagnose og dermed korrekt behandling.
}

Se kommentar side 496 og kunnskapsprøve på www.tidsskriftet.no/quiz

\author{
Christine Olbjørn \\ colb@ahus.no \\ Hans-Olav Fjærli \\ Barne og ungdomsklinikken \\ Akershus universitetssykehus \\ 1478 Lørenskog
}

En tre år gammel jente ble lagt inn i barneavdelingen med sterke magesmerter og høy feber. Foreldrene var fetter og kusine med opprinnelse fra Midtøsten. De hadde tre eldre barn som var friske. Ved innleggelsen var pasienten medtatt, blek, hadde sterke magesmerter og feber opp mot $40^{\circ} \mathrm{C}$. Ved undersøkelse var det normal organstatus, men laboratorieprøver viste forhøyet nivå av $S R$ $(40 \mathrm{~mm} / \mathrm{t}$ ) og CRP (200 mg/l) samt leukocytose med venstreforskyvning. Hemoglobinog MCV-verdiene var lett nedsatt, og hun hadde lave jernlagre. De forhøyede inflammasjonsmarkørene gjorde at man initialt lette etter en akutt bakteriell infeksjon.

Hos barn med feber og tegn til infeksjon er de vanligste årsakene pneumoni, nyrebekkenbetennelse, sepsis og osteomyelitt. Mindre vanlige årsaker er septisk artritt og akutt appendisitt.

Ved utredning fant man intet infeksjonsfokus. Det var normal urin og ingen oppvekst $i$ blodkultur. Røntgen thorax og røntgen oversikt abdomen, ultralyd abdomen og skjelettscintigrafi var alle normale. Man ventet derfor med å sette i gang antibiotikabehandling. Feberen varte i tre dager. Da den sank, ble også inflammasjonsmarkørene normalisert, og jenta ble utskrevet i god allmenntilstand, afebril og uten magesmerter.

Hun ble reinnlagt to uker senere med samme sykdomsbilde. I tillegg hadde hun leddsmerter og ville ikke stå på beina. Heller ikke denne gang kunne man påvise infeksjonsfokus. Utvidede laboratorieprøver ble tatt. Aktuelt agens kunne ikke påvises ved serologiske undersøkelser. Det var normale verdier for transaminaser, kreatinin, immunglobuliner, albumin, TSH, fritt T4, elektrolytter, syre/base og blodsukker. Siden foreldrene var i slekt, ble det tenkt på metabolsk sykdom som årsak, men metabolsk screening i urin var negativ. På grunn av magesmertene ble kalprotektin i feces målt for å se etter inflammasjon i tarmen. Hos pasienten var kalprotektinnivået normalt, så diagnosen inflammatorisk tarmsykdom var lite trolig. Malign bakenforliggende tilstand ble også vurdert, men normale inflammasjonsmarkører utenom anfallene og normal differensialtelling med normalt utstryk gjorde dette mindre sannsynlig. Det ble tatt glutenantistoffer for å se etter cøliaki. IgA-antigliadin var normal, men det ble påvist forhøyet $\lg A$-antitransglutaminase.

Forhøyet IgA-antitransglutaminase er som regel forenlig med cøliaki, men diagnosen må verifiseres med tynntarmsbiopsi.

Pasienten ble gastroskopert, og tynntarmsbiopsiene viste funn forenlig med cøliaki redusert tottehøyde og økt antall intraepiteliale lymfocytter. Hun ble satt på glutenfri kost. Glutenantistoffene normaliserte seg. Hun ble noe bedre, men hadde fortsatt residiverende anfall med magesmerter, feber og forhøyede inflammasjonsmarkører. Anfallene kom etter hvert hyppigere, opptil flere ganger $i$ uken. Mellom anfallene var hun feberfri, med normale CRP- og SR-verdier.

Differensialdiagnostisk tenkte vi på tilstander som gir periodevis og residiverende feber. Pasienten var født og oppvokst i Norge, så importsykdom som for eksempel malaria var lite trolig. Periodisk feber med aftøs stomatitt, faryngitt og adenitt (PFAPA-syndrom) er en aktuell differensialdiagnose hos barn. Symptomene ved denne tilstanden kommer vanligvis før fem års alder og forsvinner som regel spontant etter 4-8 år (1). Feberen kommer i regelmessige intervaller, gjerne med tre til seks ukers mellomrom, og er kjennetegnet ved samtidig cervikal glandelsvulst, faryngitt og aftøs stomatitt. Prednisolon kuperer feberen. Symptomene til vår pasient passet ikke med dette, hun hadde normale funn i fauces, ingen glandelsvulst, og feberintervallene var ikke regelmessige eller forutsigbare.

Syklisk nøytropeni gir også periodevis og residiverende feber. Syndromet klassifiseres ved lavt antall nøytrofile celler. Vår pasient hadde febril leukocytose med forhøyet antall nøytrofile celler, så dette passet ikke.

I starten virket hun mest plaget av magesmertene, men etter hvert ble det tydelig at hun samtidig hadde sterke leddsmerter. Man vurderte derfor om hun kunne ha juvenil revmatoid artritt av typen Stills syndrom.

De høye inflammasjonsmarkørene passet med dette, men feberen ga seg alltid spontant etter noen dager, og CRP- og SR-verdiene ble også normalisert. Ved Stills syndrom ville man forvente at feberen var mer langvarig, uten abrupt fall og uten normalisering av inflammasjonsmarkørene.

Pasienten var negativ for antistoff mot sykliske, citrullinerte proteiner (anti-CCP) og revmafaktor. Andre autoantistoffer hadde hun heller ikke, så juvenil artritt var lite sannsynlig.

Pasientens foreldre var i slekt, noe som gir $ø k t$ risiko for arvelige sykdommer. Vi begynte å tenke på muligheten at hun kunne ha et arvelig febersyndrom. Pasienter med hyper-IgD-syndrom har feber, magesmerter, artralgier, hovne lymfeknuter, eventuelt splenomegali og høy IgD. Anfallene er selvbegrensende, og pasienten føler seg frisk mellom feberepisodene. Dette syndromet blir autosomalt recessivt nedarvet, forekommer oftere hos nederlendere enn hos andre og er forårsaket av en mutasjon i genet som koder for mevalonatkinase. Defekten forårsaker lavere enzymaktivitet og fører til persisterende forhøyet IgD og hovne lymfeglandler på halsen (2).

Vår pasient hadde normale lymfeknuter, ingen hepatosplenomegali og normal $\lg D$, så hyper-lgD-syndrom ble utelukket.

Tumornekrosefaktorreseptorassosiert periodisk syndrom er en tilstand som gir feber $\mathrm{i}$ 4-6 dager og magesmerter. Plagsom myalgi, konjunktivitt og unilateralt periorbitalt ødem er som regel en del av tilstanden, det samme er veldefinerte erysipelasliknende lesjoner, som kan lokaliseres på hele kroppen (3). Sykdommen er autosomalt dominant arvelig og hyppigst beskrevet hos irer 
og skotter. Den er forårsaket av mutasjoner i genet som koder for tumornekrosefaktorreseptor på kromosom 12p13 og fører til forstyrrelser i cytokinreseptorbalansen. Vår pasient manglet flere av symptomene som er typiske for dette syndromet. Dessuten var hennes foreldre fra Midtøsten, så verken symptombilde eller genetisk opprinnelse passet med denne tilstanden.

På grunn av pasientens opprinnelse og symptombilde ble diagnosen familiær middelhavsfeber mistenkt. Blodprøve til genetisk undersøkelse bekreftet at hun var homozygot for en av de hyppigste genmutasjonene som gir tilstanden, M649V.

Familiær middelhavsfeber er en sjelden tilstand i Norge, men hyppig i middelhavslandene hos jøder, tyrkere, armenere og arabere. Bærerhyppigheten hos disse kan være så høy som hos opptil en av tre (4). Arvegangen er autosomalt recessiv.

$M E F V$-genet, som koder for sykdommen, er lokalisert på den korte armen til kromosom 16. Genet koder for et protein som har betydning for nedreguleringen av betennelse. Dersom genet er mutert, får pasienten episoder med feber og en massiv tilstrømming av leukocytter til serøse membraner (5). Sykdommen manifesterer seg ofte før fem års alder, noen ganger så tidlig som etter få uker. Vår pasient hadde hatt symptomer fra ettårsalderen.

Anbefalt behandling ved denne tilstanden er kolkisin, som virker ved å hemme leukocyttkjemotaksisen gjennom en direkte effekt på leukocyttenes mikrotubuli. Kolkisin kan også redusere ekspresjonen av adhesive molekyler på hvite blodceller og endotelceller, slik at færre leukocytter strømmer til inflammasjonsområdet (6). Kolkisin forebygger anfall, men er ikke virksomt dersom anfallet har startet. Medisinen må tas regelmessig, seponering kan føre til anfall med feber og smerter i løpet av et døgn. Anfall forebygges med peroral kolkisin 1-2 mg/dag fordelt på to doser. Behandlingen forhindrer også danning av amyloid. Opphopning av amyloid i forskjellige organer, med predileksjon i nyrene, er den alvorligste komplikasjonen ved familiær middelhavsfeber og kan føre til nyre- og hjertesvikt. 5-10\% prosent er ikkerespondere. Selv disse bør stå på kolkisin, da det er vist at dette forhindrer amyloidoseutvikling (6). Bivirkninger av kolkisin kan være diaré, kvalme, oppkast og magesmerter. Antallet erytrocytter og leukocytter kan falle, men stiger vanligvis til normalnivå ved reduksjon av dosen. Stigning av transaminaseverdier forekommer (7).

I vanskelige tilfeller med inkomplett remisjon på kolkisin prøves nyere behandlingsformer, inkludert hemmere av tumornekrosefaktor, interleukin-1-reseptorantagonister, alfainterferon, thalidomid og planteekstrakter (8). Kolkisin er ikke like effektivt til å motvirke leddsmerter og leddsymptomer.
Ved artritter og artralgier er det anbefalt å legge til ikke-steroide antiinflammatoriske midler som smertelindring.

\section{Det ble startet behandling med kolkisin. Dette} ga bedring - det ble færre episoder med feber og magesmerter. Det ble imidlertid ingen komplett remisjon. Utredning viste at jenta var Helicobacter pylori-positiv, og det ble gitt trippelkur for eradikasjon av bakterien. Dette ga noe lindring - færre og mildere anfall med magesmerter. Man prøvde deretter å øke kolkisindosen for å bedre symptomene, men dette gav plagsom diaré, nattlige defekasjoner og forhøyede transaminaseverdier. Dosen måtte derfor reduseres.

På grunn av gjentatte anfall med feber og smerteanfall på tross av kolkisinbehandling ble hun henvist til barnerevmatologisk seksjon ved Rikshospitalet for vurdering. Man besluttet der å utvide behandlingen med en tumornekrosefaktorhemmer, etanercept (Enbrell, 0,8 mg/kg en gang per uke subkutant. I tillegg fikk pasienten ibuprofen $200 \mathrm{mg}$ daglig pga. leddplagene. Behandlingen med kolkisin, etanercept og ibuprofen førte til sjeldnere og mildere feberanfall, uten ledsagende magesmerter. Leddplagene er imidlertid fortsatt betydelige, med smerter, morgenstivhet og intoleranse for kulde. Blodprøver blir kontrollert jevnlig for å vurdere terapiresponsen og eventuelle bivirkninger. Hun har fortsatt et glutenfritt kosthold - har vokst fint og krysset oppover på prosentilene. Familien har fått genetisk veiledning.

\section{Diskusjon}

Hos barn med selvbegrensende, men kronisk tilbakevendende feberepisoder er det viktig å identifisere den bakenforliggende sykdommen som utløser feberen.

Familiær middelhavsfeber karakteriseres av gjentatte episoder med feber og smertefull polyserositt (9). Serositten kommer til uttrykk som magesmerter, artritter, artralgier og/eller pleuritt. Anfallene varer i timer til dager og er selvbegrensende. Magesmertene kan være så kraftige at noen blir operert på mistanke om for eksempel akutt appendisitt. Brystsmertene er generelt ensidige og kan være så alvorlige at pasienten vegrer seg for å puste dypt. Ved leddaffeksjon rammes oftest ett ledd om gangen, vanligvis en ankel eller et kne, og leddet kan være hovent og så smertefullt at barnet ikke vil gå. Over det affiserte leddet får omtrent en tredel et rødt utslett som kan vare i opptil to uker, og hos ca. $5 \%$ kan artritten bli kronisk (5). Mellom anfallene er pasientene symptomfrie, med normale inflammasjonsmarkører.

Man vet at familiær middelhavsfeber forekommer hyppigere ved inflammatoriske tarmsykdommer som Crohns sykdom, ved vaskulitter som Henoch-Schønleins purpura, polyarteritis nodosa og ved Behçets sykdom (9). Behçets sykdom er en viktig differensialdiagnose til familiær middelhavsfeber, da sykehistorien kan likne. Den største forskjellen er at feberen vanligvis varer lenger ved Behçets sykdom, ofte mer enn en uke, mot 1-3 dager ved familiær middelhavsfeber. Behçets sykdom responderer ikke spesielt godt på kolkisinbehandling.

Vår pasient hadde cøliaki i tillegg, og vi lette etter en assosiasjon mellom cøliaki og familiær middelhavsfeber. Det har vært diskutert om sistnevnte forekommer hyppigere ved cøliaki, men studier har ikke sikkert kunnet vise dette (10). En studie har vist overhyppighet av IgA-antistoffer mot gliadin hos pasienter med familiær middelhavsfeber (11). IgA-antigliadin kan imidlertid være positiv av andre årsaker og er ikke spesifikk for cøliaki.

\section{Konklusjon}

Gjentatte episoder med høy feber, magesmerter, brystsmerter og/eller leddsmerter hos barn med opprinnelse fra middelhavsland bør gi mistanke om familiær middelhavsfeber. Etter påbegynt behandling med kolkisin ble vår pasient bedre. Behandlingen er viktig for å forebygge amyloidose. Tett oppfølging er nødvendig, da det kan være vanskelig å skille oppblussing av grunnsykdommen fra andre akutte tilstander hos barn. I litteraturen kunne vi ikke finne noen sikker overhyppighet av cøliaki sammen med familiær middelhavsfeber, men cøliaki er en viktig differensialdiagnose.

Pasientens pårørende har gitt samtykke til at artikkelen blir publisert.

Oppgitte interessekonflikter: Ingen

Litteratur

Øymar K, Kristoffersen EK. Periodisk feber-syndrom hos barn. Tidsskrift Nor Lægeforen 2007 127: $1651-3$

2. Livneh A, Drenth JP, Klasen IS et al. Familial Mediterranean fever and hyperimmunoglobulinemia D syndrome: two diseases with distinct clinical, serologic and genetic features. J Rheumatol 1997 24: $1558-63$

3. Majeed HA. Differential diagnosis of fever of unknown origin in children. Curr Opin Rheumatol 2000: 12: 439-44

4. Touitou I. The spectrum of familal Mediterranean fever (FMF) mutations. Eur J Hum Genet 2001; 9: 473-83.

5. Orbach H, Ben-Chetrit E. Familial Mediterranean fever - a review and update. Minerva Med 2001; 92 421-30.

6. Livneh A, Langevitz P. Diagnostic and treatment concerns in familial Mediterranean fever. Baillieres Best Pract Res Clin Rheumatol 2000; 14: 447-98.

7. Zemer D, Livneh A, Danon YL et al. Long-term colchicine treatment in children with familial Mediterranean fever. Arthritis Rheum 1991; 34: 973-7.

8. Tunca M, Ben-Checrit E. Familial Mediterranean fever in 2003. Pathogenesis and management. Clin Exp Rheumatol 2003; 21 (suppl 30): S49-S52.

9. Sohar E, Gafni J, Pras M et al. Familial Mediterranean fever: a survey of 470 cases and review of the literature. Am J Med 1967: 43: 227-53.

10. Mor A, Mekori YA, Livneh A. Familial Mediterranean fever and celiac sprue - are they related? Clin Exp Rheumatol 2004; 22 (4 suppl 34): 82.

11. Yilmaz $\emptyset$, Kirdar S, Dogan Y et al. Comparison of serum antigliadin and antiendomysium antibodies in patients with familial Mediterranean fever. Turk Mikrobiyol Cem Derg 2007; 37: 98-102.

Manuskriptet ble mottatt 30.4. 2008 og godkjent 29. 10. 2009. Medisinsk redaktør Odd Terje

Brustugun. 